\title{
cGMP and PKGI are required for vascular BMP signaling
}

\author{
Raphaela Schwappacher ${ }^{*}$, Thuan Diep, Gerry Boss, Renate Pilz \\ From 5th International Conference on cGMP: Generators, Effectors and Therapeutic Implications \\ Halle, Germany. 24-26 June 2011
}

\section{Background}

Maintenance of vascular homeostasis depends on phenotypic switching of vascular smooth muscle cells (VSMCs) during development, vascular injury repair, and disease. In healthy blood vessels, VSMCs exhibit a differentiated, 'contractile' phenotype, but in diseased vascular tissue or after vascular injury, they de-differentiate into a 'synthetic' state, characterized by decreased smooth muscle (SM)-specific gene expression and increased proliferation and motility [1].

\section{Results}

Although still controversial, a large number of studies indicate that the NO/cGMP/PKGI pathway inhibits proliferation and de-differentiation of VSMCs. Subcultured primary VSMCs undergo de-differentiation to a 'synthetic' phenotype with both reduced SM-specific gene expression and loss of PKGI expression. A more 'contractile' phenotype can be regained by restoring PKGI [2]. PKGI stimulates SM-specific gene expression through regulation of the cystein-rich LIM only protein CRP4 that cooperates with SRF-containing transcription complexes [3]. But the mechanism how cGMP/PKGI regulates $\mathrm{SM}$-specific phenotype is incompletely understood. In C2C12 myoblasts, PKGI phosphorylates the BMP type II receptor (BMPRII); in response to BMP-2, PKGI dissociates from the receptor, associates with the activated Smad1/4 complex, translocates to the nucleus, and forms a complex with Smads and the general transcription factor TFII-I to collaboratively activate transcription [4]. In the vascular system, BMP signaling inhibits proliferation and migration of VSMCs, and upregulates SM-specific genes, through Smad-dependent

\footnotetext{
* Correspondence: rschwappacher@ucsd.edu Department of Medicine, University of California at San Diego, San Diego, CA 92093, USA
}

[5-8] and/or Smad-independent pathways [9-11]. Interestingly, heterozygous germline mutations within BMPRII can cause pulmonary arterial hypertension $(\mathrm{PAH})$, a disease characterized by thickening of pulmonary arteries due to abnormal proliferation, migration, and/or apoptosis of VSMCs and endothelial cells [12]. Considering these data we hypothesize that PKGI promotes the differentiated 'contractile' phenotype of VSMCs at least in part through enhancing vascular $\mathrm{BMP} / \mathrm{Smad}$ signaling. Indeed we found that cGMP/ PKGI promoted Smad1/5 activation and BMP target gene expression in VSMCs and SM precursor cells. Pharmacological or siRNA-mediated inhibition of the NO/cGMP/PKGI pathway not only suppressed BMPinduced upregulation of SM-specific gene transcription, but also abrogated the anti-proliferative and anti-migratory effects of BMP on VSMCs. Furthermore preliminary data suggest that Smad crosstalk with other transcriptional regulators is involved.

\section{Conclusion}

Our data imply that within the vasculature, PKGI is a critical regulator of the VSMC differentiation-promoting effects of BMP. The integration of cGMP/PKGI pathway into $\mathrm{BMP} / \mathrm{Smad}$ signaling in the vascular system might provide new insight into the mechanisms of vascular remodeling in diseases such as atherosclerosis, vascular restenosis and pulmonary hypertension.

\section{Published: 1 August 2011}

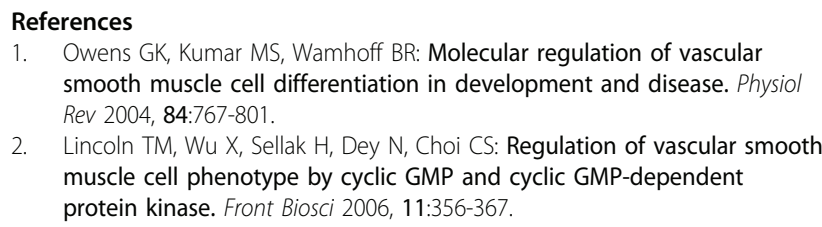

1. Owens GK, Kumar MS, Wamhoff BR: Molecular regulation of vascular smooth muscle cell differentiation in development and disease. Physiol Rev 2004, 84:767-801.

2. Lincoln TM, Wu X, Sellak H, Dey N, Choi CS: Regulation of vascular smooth muscle cell phenotype by cyclic GMP and cyclic GMP-dependent protein kinase. Front Biosci 2006, 11:356-367.

\section{() Biomed Central}


3. Zhang T, Zhuang S, Casteel DE, Looney DJ, Boss GR, Pilz RB: A cysteine-rich LIM-only protein mediates regulation of smooth muscle-specific gene expression by cGMP-dependent protein kinase. J Biol Chem 2007, 282:33367-33380.

4. Schwappacher R, Weiske J, Heining E, Ezerski V, Marom B, Henis YI, Huber O, Knaus P: Novel crosstalk to BMP signalling: CGMP-dependent kinase I modulates BMP receptor and Smad activity. EMBO J 2009, 28:1537-1550.

5. Lagna G, Ku MM, Nguyen PH, Neuman NA, Davis BN, Hata A: Control of phenotypic plasticity of smooth muscle cells by bone morphogenetic protein signaling through the myocardin-related transcription factors. J Biol Chem 2007, 282:37244-37255.

6. Chan MC, Hilyard AC, Wu C, Davis BN, Hill NS, Lal A, Lieberman J, Lagna G, Hata A: Molecular basis for antagonism between PDGF and the TGFbeta family of signalling pathways by control of miR-24 expression. Embo J 2010, 29:559-573.

7. Davis BN, Hilyard AC, Lagna G, Hata A: SMAD proteins control DROSHAmediated microRNA maturation. Nature 2008, 454:56-61.

8. Chan MC, Weisman AS, Kang H, Nguyen PH, Hickman T, Mecker SV, Hill NS, Lagna G, Hata A: The amiloride derivative phenamil attenuates pulmonary vascular remodeling by activating NFAT and the bone morphogenetic protein signaling pathway. Mol Cell Biol 2011, 31:517-530.

9. Hansmann G, de Jesus Perez VA, Alastalo TP, Alvira CM, Guignabert C, Bekker JM, Schellong S, Urashima T, Wang L, Morrell NW, Rabinovitch M: An antiproliferative BMP-2/PPARgamma/apoE axis in human and murine SMCs and its role in pulmonary hypertension. J Clin Invest 2008, 118:1846-1857.

10. Yang J, Li X, Al-Lamki RS, Southwood M, Zhao J, Lever AM, Grimminger F, Schermuly RT, Morrell NW: Smad-dependent and smad-independent induction of id 1 by prostacyclin analogues inhibits proliferation of pulmonary artery smooth muscle cells in vitro and in vivo. Circ Res 2010, 107:252-262.

11. Perez VA, Ali Z, Alastalo TP, Ikeno F, Sawada H, Lai YJ, Kleisli T, Spiekerkoetter E, Qu X, Rubinos LH, Ashley E, Amieva M, Dedhar S, Rabinovitch M: BMP promotes motility and represses growth of smooth muscle cells by activation of tandem Wnt pathways. J Cell Biol 2011, 192:171-188.

12. Morrell NW: Role of bone morphogenetic protein receptors in the development of pulmonary arterial hypertension. Adv Exp Med Biol 2010, 661:251-264.

doi:10.1186/1471-2210-11-S1-P65

Cite this article as: Schwappacher et al:: CGMP and PKGI are required for vascular BMP signaling. BMC Pharmacology 2011 11(Suppl 1):P65.

\section{Submit your next manuscript to BioMed Central and take full advantage of:}

- Convenient online submission

- Thorough peer review

- No space constraints or color figure charges

- Immediate publication on acceptance

- Inclusion in PubMed, CAS, Scopus and Google Scholar

- Research which is freely available for redistribution

Submit your manuscript at www.biomedcentral.com/submit
Biomed Central 